\title{
The Legacy of U.S. Educational Leadership: Notes on Distribution and Economic Growth in the 20th Century
}

\section{Citation}

Goldin, Claudia, and Lawrence F Katz. 2001. "The Legacy of U.S. Educational Leadership: Notes on Distribution and Economic Growth in the 20th Century." American Economic Review91 (2): 1823. https://doi.org/10.1257/aer.91.2.18.

\section{Permanent link}

http://nrs.harvard.edu/urn-3:HUL.InstRepos:41534598

\section{Terms of Use}

This article was downloaded from Harvard University's DASH repository, and is made available under the terms and conditions applicable to Other Posted Material, as set forth at http:// nrs.harvard.edu/urn-3:HUL.InstRepos:dash.current.terms-of-use\#LAA

\section{Share Your Story}

The Harvard community has made this article openly available. Please share how this access benefits you. Submit a story.

Accessibility 


\title{
The Legacy of U.S. Educational Leadership: Notes on Distribution and Economic Growth in the 20th Century
}

\author{
By Claudia Goldin and Lawrence F. Katz*
}

The United States led all rich and industrialized countries in the establishment of mass secondary and higher education, and it led all in Europe by at least several decades for much of the 20th century. The U.S. advantage in the schooling of its young produced, by midcentury, large differences between the educational stock of its labor force and that of other rich countries, a result that would hardly be surprising except for the fact that the United States had absorbed millions of less-educated immigrants. Only in recent decades have many rich countries caught up to, and even exceeded, the United States in years of education for young persons.

At the same time that the United States led the world in mass education in the 20th century, it rapidly expanded its economic lead. No single factor can account for the economic dominance of the United States in the 20th century, and most of the favored explanations, be they rooted in technological, institutional, or natural resource factors, are complementary ones. Despite that admonition, it would appear logical that part, possibly a major part, of the economic precedence of the United States came from its enormous lead in education.

We briefly summarize the facts about the U.S. educational lead during most of the 20th century and suggest why the United States led in formal schooling. We then comment on the probable consequences for distribution and economic growth.

The wide educational lead of the United States that emerged early in the 20th century was due almost entirely to the expansion of secondary schools, known as the "high school movement." The modern high school was crafted in the United States in the late 19th century and differed from its European progen-

* Department of Economics, Harvard University, Cambridge, MA 02138, and the National Bureau of Economic Research. itor by providing training for life rather than mainly for further education in college. In 1910, less than 10 percent of young people in the United States graduated from high school, but by 1940 the median 18-year-old was a highschool graduate (Goldin, 1998). By the 1940's the majority of U.S. youth could embark on the transformation to mass higher education.

In Europe, on the other hand, the provision of formal secondary school education was, for most of the first half of the 20th century, generally limited to a small cadre of youth whose families could afford the private expense or who had scored sufficiently well on an examination taken around age 11. European policymakers viewed egalitarian education in the United States as "wasting" resources by schooling the masses.

\section{Why the United States Led in Secondary School Education}

Europe differed from the United States in its commitment to mass public education for a variety of reasons. There was less geographic mobility within European nations, educational decision-making was far more centralized, wealth levels were lower, and industrial employment was, as in the case of Great Britain, a greater fraction of the labor force. Because European nations were more culturally homogeneous than was the U.S. population, the existence of small decision-making units in the United States was an important factor in its early educational expansion. The long-standing commitment of the United States to democratic ideals is the most basic difference of all and modified the others.

The role of economic and cultural differences in affecting investment in formal education bears some discussion. When geographical and occupational mobility are low, young people will more often be taught skills by relatives and others in close proximity. The transmission of 
specialized skills through apprenticeships, onthe-job training, and other informal means will dominate the acquisition of more flexible skills in schools and other formal educational settings. In the United States, with its vast continent and a population continually on the move, schoolbased and general education made more sense than in Europe.

The highly centralized form of fiscal control that characterized many European countries was a hindrance to the early diffusion of public education. In contrast, the United States contained thousands of fiscally independent school districts. If just less than a majority of the voting population wants public secondary education, highly centralized decision-making will bring forth none. Decision-making by small and relatively homogeneous districts, however, could result in public secondary schooling for a substantial minority of the school-aged population. The early expansion of the franchise in the United States also played a major role in educational advance for the masses, and within the United States, those places that hindered universal suffrage had lower educational attainment.

Countries in which Catholicism was the dominant or state religion found less of a rationale in religious doctrine to fund mass secondary education, whereas those in which Protestant religions flourished had earlier and more complete mass secondary schooling. Within the United States, states with relatively more New England Protestants, the "progeny" of John Calvin and Martin Luther (this applies as well to the descendants of Moses and of Joseph Smith) had the highest levels of secondary-school rates, and one of the best predictors of $\mathrm{K}-12$ educational performance more recently is the relative prevalence of these groups in the 1920's.

Why did formal, mass secondary schooling advance rapidly in the United States but more slowly in Europe, and why did the United States take the lead in education throughout most of the 20th century? Although data limitations prevent us from addressing the comparative question rigorously, we can look at the variation within the United States to gain some insights. Considerable variation existed within the United States at the state and city levels, the aggregation units available to us. In 1920 , for example, the enrollment rate of 16- and 17- year-olds, across the almost 300 U.S. cities with populations in excess of 20,000 , varied from 0.16 to 0.75 , and the difference between the rates at the 90th and the 10th percentiles was 0.31. Similarly, across U.S. states, the highschool graduation rate (public and private graduates divided by 17-year-olds) in 1920 ranged from 0.07 to 0.40 , and the difference between the rate at the 90 th and the 10th percentiles was 0.21 .

States with higher secondary-school graduation rates, from 1910 to the 1930's, had greater income and taxable wealth per capita, a larger middle class (proxied by automobile registrations per capita), a larger fraction of their population in the older age group (an indicator of community stability), a lower percentage Catholic, a greater fraction attending college 20 years earlier, and a smaller proportion of their labor force in manufacturing (Goldin and Katz, 1997). Our findings are robust to estimating the relationship in levels or as the change in the (contemporaneous) high-school graduation rate on the initial levels of the independent variables and are fairly robust to a fixed-effects estimation for 1910, 1920, and 1930 .

Similarly, across U.S. cities (with more than 20,000 people in 1910) secondary schools made the greatest inroads where there was high per capita taxable wealth, low manufacturing development (particularly that involving older industries such as textiles), a high fraction of white-collar occupations among the city's workers, and a low percentage Catholic (Goldin and Katz, 1997). The city sample, because of data restrictions, does not include small cities and towns, which in many regions of the country experienced the most rapid expansion of high schools from 1910 to 1930 , possibly because they lacked lucrative youth employment and had greater homogeneity of population by ethnicity and religion.

\section{Consequences for Distribution and Economic Growth}

In previous work, we produced the first estimates of the rate of return to years of education, most importantly at the secondary and higher levels, for the United States in the period before 1940 (Goldin and Katz, 2000). We accomplished this by using a unique source, 
the Iowa State Census of 1915, from which we drew a large and representative sample (termed here the "1915 Iowa sample"). The 1915 Iowa census contains detailed individual-level data on education (in years, by type of school) and income, among other variables. Therefore, we were able to compare our results with those from 1940 and after and to chart changes in educational returns from the inception of the high-school movement in the United States.

Because we use the Iowa data extensively and treat them as being fairly representative of the nation, we should mention a few aspects of Iowa's economy in 1915. Although an agricultural state, lowa was, in 1915, as urban as was the rest of the nation, if by "urban" one means the fraction of the population residing in incorporated cities, towns, and villages. Iowa ranked second in the nation in per capita taxable wealth, due in large measure to its fertile prairie soil. It contained a somewhat less diverse population than did the entire nation: 18 percent of its labor force was foreign-born in 1910, compared with the national rate of 22 percent. More germane here is that Iowa was an educational leader since the early 20 th century.

Using the Iowa data, we estimated that the returns to a year of either secondary or higher education in 1914 were substantial, in excess of 10 percent. Because Iowa was a net exporter of educated labor, and some portion of the educational return comes from migration, we are likely to underestimate the returns to education using the 1915 Iowa sample. Returns were as high for those working in the farm sector as for those employed in cities and towns. Even within white-collar and within manual jobs, the returns to a year of education were high. That is, although part of the return to education was the ability to switch from a blue-collar to a whitecollar job, there were large gains within the two broad occupation groups.

The high rate of return to education just before World War I was, in large measure, an outgrowth of the expansion of large-scale industry, with its high demand for clerical and managerial personnel and other white-collar workers in offices and retail establishments; but it was not due to that fact alone. Many of the high-school educated in the 1920's became manual workers in the manufacturing, public utilities, and transportation sectors. Modern technologies in the "new economy" of the 1920's favored and rewarded production workers who could read manuals, decipher blueprints, and solve algebraic formulas, and who had rudimentary knowledge of chemistry and electricity, to provide just some examples of the skills employers stated they wanted (Goldin and Katz, 1998).

Of more consequence to the subject of distribution is that the returns to education declined from 1914 to 1940 . The finding is reinforced by complementary data sets bearing on distributional issues. These data reveal that the ratio of wages in various white-collar positions to that for manual jobs also declined over the period and that the wage structure for production workers within major manufacturing industries compressed from 1890 to 1940 (Goldin and Katz, 2001). It is well known that similar indicators decreased or narrowed during the 1940's. What was not known is that they also declined substantially in the several previous decades.

Much research in the area of distribution and inequality has focused on the period since the late 1970 's, one characterized by an expanding wage structure and increasing returns to years of education. We can now see that economic inequality across the entire 20th century has been a tale in two parts: first declining and then rising. What can account for the odd distributional tale of two half-centuries?

The rate of skill-biased technological change was rapid throughout the 20th century, almost as rapid from 1890 to 1929 in U.S. manufacturing as from 1959 to 1989 (Goldin and Katz, 1998). Thus, the explanation for the narrowing wage structure from the 1910's through the 1940 's is not that skill-biased technological change was slow. Rather, it is that the growth of the relative supply of more-educated labor accelerated with the high-school movement (Goldin and Katz, 1995). Other factors were complementary, to be certain, including unionization, the sharp reduction in immigration, and the two world wars. Similarly, the favored explanation for the tale of the second half of the century (rising skill differentials since the late-1970's) is a slowdown in the growth of the relative supply of more-educated workers and a more rapid increase in the rate of skillbiased technological change, at least in the 1980's. 
Many studies have found that countries with more-educated labor forces experience higher rates of economic growth. More difficult to determine is the extent to which the positive relationship between education and growth results from the causal impact of education on growth and not from reverse causation or from confounding factors correlated with both education and growth. Educational advance can contribute directly to economic growth by increasing the human capital and thus the productivity of the work force, and indirectly by increasing the rate of innovation and adoption of new technologies. The direct effect of education is the least controversial and can be computed in a simple growth accounting context.

We estimate the direct contribution to economic growth of increases in the educational attainment of the U.S. labor force from 1915 to 1999. No previous growth-accounting calculations have been able to compute the impact of education for the period of the high-school movement using educational wage differentials existing before 1940 .

We employ a standard growth-accounting framework of the type pioneered by Edward F. Denison (1962) and compute an educational productivity index $\left(E_{f}\right)$ of the U.S. work force for selected years, $t$. The index measures the productivity of workers with different education levels by computing the relative wage of each education group, adjusted for differences in potential experience, sex, race, and nativity. That is, we compute $E_{t}=\sum_{i} w_{i \tau} S_{i t}$, where $w_{i \tau}$ is the (adjusted) wage of education group $i$ (relative to a reference education group) in base period $\tau$, and $S_{i t}$ is the share of education group $i$ in employment (or total hours) in year $t$. The growth in $E_{t}$ measures the contribution of educational upgrading to aggregate labor-input growth. The impact of educational expansion on economic growth is the log change in the index times labor's share of national product (which has remained at about 0.7 across the 20th century). Two components are needed to compute the educational productivity index: $S_{i t}$ and $w_{i r}$.

We measure $S_{i t}$, the educational composition of the national and Iowa labor forces, using data from the Integrated Public Use Microsamples (IPUMS) of the population censuses for 19401980 and using the Current Population Survey Merged Outgoing Rotation Groups for 1999.
We extend the analysis back to 1915 for Iowa using the 1915 Iowa sample. The $w_{i t}$ 's are based on national estimates of educational wage differentials in each period, starting in 1940, and are obtained by estimating log earnings regressions for nonfarm workers, 18-65 years old, on educational group dummies and other relevant covariates (see notes to Table 1). We estimate educational wage differentials for Iowa in 1915 using a similar technique and adjust the 1915 Iowa estimates to be nationally representative by assuming that the difference between education returns in Iowa and the nation was the same in 1915 as it actually was in 1940.

We directly estimate the growth in the educational attainment of the Iowa work force for the period of the high-school movement using the 1915 Iowa sample and the 1940 IPUMS. We assume that the national change in the educational productivity index from 1915 to 1940 equals that for Iowa, a reasonable assumption since "backcasting" to 1915 the educational attainment of the U.S. and Iowa work forces, using the 1940 IPUMS, produces similar increases.

We compute educational productivity indexes that are chain-weighted, and those that use fixed weights. The chain-weighted index measures the contribution of education to productivity in each subperiod by the educational wage differentials prevailing in that period. In contrast, the fixed-price index applies average educational wage differentials (in this case for 1915,1960 , and 1999) to all subperiods.

The results of these tabulations are presented in Table 1. On average, the educational productivity of the U.S. work force expanded by 0.53 percent annually from 1915 to 1999 using the chain-weighted index and by 0.55 using the fixed-price index. The direct impact on economic growth of the expanding education of the work force was about 0.37 percent per year $(0.53 \times 0.7)$ since 1915, and the educational factor accounts for 23 percent of the 1.62-percent per-year increase in U.S. labor productivity (nonfarm, nonhousing business GDP per. worker for 1913-1996) (from Robert J. Gordon, 2000).

The chain-weighted index shows that the period of the high-school movement, 1915-1940, was one of rapid growth in the educational input (0.55 percent per year). Only during 19601980, decades of exceptional expansion in higher education and the labor-force entry of 
Table 1-Education's Role in Economic Growth, 1915-1999: IOWA AND THE UNITED STATES

$(100 \times$ AnNual Log Change in Labor-ForCE EduCational, Productivity IndeX)

\begin{tabular}{|c|c|c|c|c|}
\hline A. Chain-We & \multicolumn{2}{|c|}{ United States } & Iowa & \\
\hline Time period & Employment & Hours & Employment & Hours \\
\hline $1915-1940^{a}$ & 0.55 & n.a. & 0.55 & n.a. \\
\hline $1940-1960$ & 0.51 & 0.50 & 0.39 & 0.39 \\
\hline $1960-1980$ & 0.63 & 0.64 & 0.55 & 0.58 \\
\hline 1980-1999 & 0.43 & 0.43 & 0.39 & 0.39 \\
\hline $1915-1999^{b}$ & 0.53 & n.a. & 0.47 & n.a. \\
\hline
\end{tabular}

B. Fixed-Weight Prices

\begin{tabular}{lccccc} 
& \multicolumn{2}{c}{ United States } & & \multicolumn{2}{c}{ Iowa } \\
\cline { 2 - 3 } \cline { 5 - 6 } Time period & Employment & Hours & & Employment & Hours \\
\hline $1915-1940^{\mathrm{a}}$ & 0.47 & n.a. & & 0.47 & n.a. \\
$1940-1960$ & 0.54 & 0.54 & & 0.44 & 0.45 \\
$1960-1980$ & 0.75 & 0.76 & & 0.68 & 0.71 \\
$1980-1999$ & 0.44 & 0.44 & & 0.41 & 0.39 \\
$1915-1999$ & 0.55 & n.a. & & 0.50 & n.a. \\
\hline
\end{tabular}

Notes: Educational productivity index for year $t=\sum_{i} w_{i \tau} S_{i t}=$ $E_{t}$, where $S_{i t}=$ employment (or hours) share of education group $i$ in year $t$, and $w_{i \tau}=$ adjusted wage of education group $i$ in base year $\tau$. Chain-weighted index during time period ( $t$ to $\left.t^{\prime}\right): w_{i \tau}$ are average educational wage differentials in $t$ and $t^{\prime}$. Fixed-weight index: $w_{i \tau}=\bar{w}_{i}=$ average educational wage differential in 1915, 1960, and 1999. Reported numbers are $\left[100 /\left(t^{\prime}-t\right)\right] \times \ln \left(E_{t} / E_{t}\right) \approx$ annual percentage change from $t$ to $t^{\prime}$. Values of $w_{i t}$ are based on $\log$ annual (hourly in 1999) earnings regressions in each year $t$ for nationally representative samples of full-year (full-time in 1999), nonfarm, wage and salary workers aged 18-65 years for 1940-1999. Values of $w_{i t}$ for 1915 use the 1915 Iowa sample which includes the selfemployed; the 1915 estimates are adjusted to reflect national educational returns by assuming the difference in educational wage differentials between Iowa and the United States to be the same in 1915 as in 1940 . Education groups are $0-4,5-7$, $8,9-11,12,13-15$, and $16+$ years for the chain-weighted 1915-1980 estimates; a single 5-8 group replaces the corresponding two categories for all the fixed-weight estimates and for the chain-weighted estimate for 1980-1999. Log earnings regressions include educational-group dummies, quartic in experience, female dummy, female $\times$ quartic in experience, and white and foreign-born dummies. The $S_{i t}$ data include all workers $18-70$ years old.

Sources: 1915 Iowa sample (Goldin and Katz, 2000); 1940, 1960, and 1980 Integrated Public Use Microsamples of the U.S. population census; 1999 Current Population Survey Merged Outgoing Rotation Groups.

a The U.S. figure is equal to that for Iowa, by assumption.

b The average of the growth rates in the intermediate periods weighted by the interval length.

baby-boom cohorts, was there a greater impact of education growth. Also evident in Table 1 is the reduction in the growth of educational pro- ductivity since 1980 , despite the large increase in educational returns. The culprits for the reduction are several and include the slowdown, since the 1970's, in the growth of educational attainment among labor-force entrants (especially men) and the smaller relative size of labor-force cohorts with the baby-bust generations. The patterns for Iowa are similar to those of the nation but reveal a slower expansion in educational productivity since 1940, not surprising in this early high-education state.

The period of the high-school movement appears to have been one of rapid increase in educational productivity. But did it usher in a new era in terms of the role of education in economic growth? Differences in educational attainment by cohort in the 1915 Iowa sample allow us to "backcast" the educational attainment of the Iowa work force in 1890 and thus provide an estimate of the growth of the educational productivity index from 1890 to 1915 . To estimate the education of the 1890 Iowa work force we observe, in 1915 , the educational attainment of Iowa residents born from 1845 to 1870. We assume that the Iowa work force in 1890 had the same age and sex composition as in 1915 and that the rate of educational advance for cohorts born from 1820 to 1845 was similar to that for those born from 1845 to 1870 . Using the national educational wage differentials from 1915 and 1940, we find that the rate of growth of the educational productivity index was 0.29 percent per annum from 1890 to 1915 or only about half as rapid as in the $1915-1940$ period of the high-school movement. Thus, the highschool movement produced an era of far more rapid expansion in the education of the work force, and it was one that persisted for nearly the rest of the 20th century.

\section{The Legacy of Educational Leadership}

The high-school movement of the 19101940 era set the United States far ahead of other countries in the educational attainment of its labor force for much of the 20th century and laid the foundations for the later transition to mass higher education. The United States took the lead in education, in part, because of institutional and political factors: a more universal franchise and decentralized decision-making. But it also did so because of greater geographic 
mobility and technological dynamism, factors that were further reinforced with more education. We have shown that higher and more universally greater levels of education narrowed the wage structure and reduced the extremely high rate of return to years of education that existed in the early part of the 20th century. We have also used the standard growthaccounting framework to isolate the direct effect of education on economic growth. We recognize, however, that the methodology largely omits a host of other ways that education affects economic growth. The legacy of America's educational leadership was a technological dynamism that blossomed in midcentury, but that is a subject for a lengthier tract.

\section{REFERENCES}

Denison, Edward F. The sources of economic growth in the United States and the alternatives before us. New York: Committee for Economic Development, 1962.

Goldin, Claudia. "America's Graduation from High School: The Evolution and Spread of Secondary Schooling in the Twentieth Century." Journal of Economic History, June 1998, 58(2), pp. 345-74.
Goldin, Claudia and Katz, Lawrence F. "The Decline of 'Non-Competing Groups': Changes in the Premium to Education, 1890 to 1940." National Bureau of Economic Research (Cambridge, MA) Working Paper No. 5202, 1995.

."Why the United States Led in Education: Lessons from Secondary School Expansion, 1910 to 1940." National Bureau of Economic Research (Cambridge, MA) Working Paper No. 6144, 1997.

"The Origins of Technology-Skill Complementarity." Quarterly Journal of Economics, August 1998, 113(3), pp. 693-732.

. "Education and Income in the Early

Twentieth Century: Evidence from the Prairies." Journal of Economic History, September $2000,60(3)$, pp. 782-818.

. "Decreasing (and Then Increasing) Inequality in America: A Tale of Two HalfCenturies," in Finis Welch, ed., The causes and consequences of increasing income inequality. Chicago, IL: University of Chicago Press, 2001, pp. 37-82.

Gordon, Robert J. "Interpreting the 'One Big Wave' in U.S. Long-Term Productivity Growth." National Bureau of Economic Research (Cambridge, MA) Working Paper No. 7752, 2000. 